\title{
Isoflavones in Soybean as a Daily Nutrient: The Mechanisms of Action and How They Alter the Pharmacokinetics of Drugs
}

\author{
Günlük Besin Olarak Soya Fasulyesindeki İzoflavonlar: Etki Mekanizmaları \\ ve İlaçların Farmakokinetiğini Değiştirmeleri
}

\author{
(D) Amelia SOYATA1 1 , (D) Aliya Nur HASANAH², (D) Taofik RUSDIANA ${ }^{1 *}$ \\ 1Padjadjaran University Faculty of Pharmacy, Department of Pharmaceutics and Pharmaceutical Technology, Sumedang, Indonesia \\ 2Padjadjaran University Faculty of Pharmacy, Department of Analysis of Pharmaceutical and Medical Chemistry, Sumedang, Indonesia
}

\begin{abstract}
Soybeans [Glycine $\max (\mathrm{L}$.$) ] are a good source of isoflavones. The main isoflavone components of soybean are daidzein, genistein, and glycitein.$ World soybean production is very high. Because of its pharmacological activity, soy isoflavone intake over a long period of time may result in interactions with the drugs. This review summarizes soy isoflavone-drug interactions based on the pharmacokinetic parameters. Soy isoflavones have pharmacokinetic interactions with celecoxib, theophylline, paclitaxel, midazolam, imatinib, carbamazepine, valproic acid, repaglinide, omeprazole and danofloxacin. This is due to the changes in the area under the curve, maximum serum concentration, time that a drug is present at the maximum concentration in serum, clearance and half-life of the drugs when delivered together with soy isoflavones. The mechanisms of pharmacokinetic interactions occurs through the inhibition/induction of drug metabolizing cytochrome P450 (CYP450) enzymes such as CYP3A4, CYP2A1, and CYP2C9 or through the inhibition of drug transporters such as P-glycoprotein and breast cancer resistance protein. Thus, the consumption of soybean, soy isoflavones or soy products with drugs needs to be reconsidered.
\end{abstract}

Key words: Soybean, isoflavones, pharmacokinetic interaction, drug metabolizing enzyme, drug transporter

öz

Soya fasulyesi [Glycine max (L.)] iyi bir izoflavon kaynağıdır. Soya fasulyesinin ana izoflavon bileşenleri daidzein, genistein ve glisitindir. Dünyada soya üretimi çok yüksektir. Farmakolojik aktivitesi nedeniyle, uzun süre soya izoflavon alımı, ilaçlarla etkileşime neden olabilir. Bu derleme, farmakokinetik parametrelere dayalı olarak soya izoflavon-ilaç etkileşimlerini özetlemektedir. Soya izoflavonları, selekoksib, teofilin, paklitaksel, midazolam, imatinib, karbamazepin, valproik asit, repaglinid, omeprazol ve danofloksasin ile farmakokinetik etkileşimlere sahiptir. Bunun nedeni, soya izoflavonları ile birlikte verildiğinde ilaçların eğrinin altındaki alan, maksimum serum konsantrasyonu, ilacın maksimum serum konsantrasyonunda bulunduğu süre, klirens ve yarılanma ömründe yaptığı değișikliklerdir. Farmakokinetik etkileșimlerin mekanizmaları ilaç metabolize eden sitokrom P450 (CYP450) enzimlerinin (örneğin; CYP3A4, CYP2A1 ve CYP2C9) inhibisyonu/indüklenmesi veya P-glikoprotein ve meme kanseri direnç proteini gibi ilaç taşıyıcılarının inhibisyonu yoluyla gerçekleşir. Bu nedenle soya fasulyesi, soya izoflavonları veya soya ürünlerinin ilaçlarla tüketimi yeniden gözden geçirilmelidir.

Anahtar kelimeler: Soya fasulyesi, izoflavonlar, farmakokinetik etkileşim, ilaç metabolize eden enzim, ilaç taşıyıcısı 


\section{INTRODUCTION}

Soybeans [Glycine max (L.)] are a source of isoflavones in the daily meals. In 2016, global soybean production amounted to be $34,894,085$ tons; with $293,414,006$ tons from the Americas, $28,808,950$ tons from Asia, 10,488,759 tons from Europe, and $2,119,814$ tons from Africa. In 2016, total of $89.05 \%$ of soybean production was from five countries: India (4.18\%), China (3.57\%), Argentina (17.56\%), Brazil (28.75\%), and the USA (34.99\%). Soybeans contain non-steroidal polyphenol compounds ${ }^{2}$ with a chemical structure similar to that of oestradiol-17 $\beta$, so these compounds may have a similar effect to that of the estrogen.,4 The main isoflavone content of soybean is in aglycone form, including genistein, daidzein, and glycitein; the glycosidic forms are genistin, daidzin, and glycitin, which are precursors of the metabolic process which forms daidzein and genistein aglycones. ${ }^{5}$ The total glycitein and glycoside content in soybeans is only $5-10 \%$ of the total isoflavones, while the remaining is comprised of daidzein and genistein. ${ }^{6}$ Isoflavones have effects on postmenopausal nutrition, ${ }^{7}$ relief of postmenopausal vasomotor symptoms, ${ }^{8}$ osteoporosis, ${ }^{9}$ inflammation, ${ }^{10}$ and cardiovascular disease. ${ }^{11}$ The compounds also have antioxidant activity, ${ }^{12}$ increase the efficacy of cancer therapy, ${ }^{13}$ and inhibit the cancer cell proliferation. ${ }^{14}$

Based on this pharmacological activity, soy isoflavones could be used as a dietary nutrition over a long period of time. Soybean consumption continued to increase in $2011 .{ }^{15}$ Fonseca et al. $^{16}$ showed that the amount of isoflavones taken in by the infants fed with soy-based formula is $0.8 \mathrm{mg} / \mathrm{day} / \mathrm{kg}$ of body weight; this number is two-fold higher than the level of isoflavones consumed by the adults in Japan. The daily intake of isoflavones is related to how much soy is consumed and differs in each country, [i.e., it is much higher in east and south Asian countries (20-50 mg/day), than in Europe (0.49-1 mg/day)].,18 To fulfill the daily nutrient needs, the Chinese government has recommended that every citizen consumes $50 \mathrm{mg}$ of soy food daily. Simple processed soy foods from Asia usually contain $3.5 \mathrm{mg}$ of isoflavones in every gram. Large studies performed in the United States showed that each adult there consumes $2.5 \mathrm{mg}$ of isoflavones per day, but other research data shows different results where the consumption of isoflavones per day may reach the range of 30-50 $\mathrm{mg}$. In China, the average daily consumption of isoflavones is $40.8 \pm 28.7 \mathrm{mg} / \mathrm{day} .^{19}$

Isoflavone consumption patterns in this community therefore raise the possibility of drug interactions when used together, so their use must be monitored. Drug interactions occur when other substances affect the activity of a drug. ${ }^{20}$ These interactions may occur with the soy isoflavones. Soy extracts, soy products, and soy isoflavones have interactions with the drugs such as: Warfarin, ${ }^{21}$ tamoxifen, ${ }^{22}$ levodopa, ${ }^{23}$ and ciprofloxacin. ${ }^{24}$ The mechanism of the drug-isoflavone interaction is by the inhibition or induction of drug metabolizing enzymes (DMEs) or drug transporters. ${ }^{25}$

Almost all the drug biotransformation reactions need a metabolic enzyme, and the enzymes most often used to process the drugs are the liver microsomal cytochrome P450 (CYP450) enzymes. The CYP enzymes involved in the drug metabolism are CYP2C9, CYP2C19, CYP2D6, CYP3A4, and CYP3A5. ${ }^{26}$ Drugs or bioactive compounds such as isoflavonoids interact with these enzymes, and change the efficacy and action of the drug. ${ }^{27}$ Soybean products (infusions) have an inhibitory effect on human CYP enzymes, including CYP2C9, CYP2C19, CYP3A4, and CYP2D6. ${ }^{28}$ It has also been reported that soy isoflavones reduce the hepatic CYP2E1 and CYP3A activities related to acetaminophen metabolism. ${ }^{29}$

Furthermore, drug transporters could be involved in the drug interactions, because drug transporters mediate the absorption, distribution, and excretion of the drugs in the transport process across the plasma membrane. ${ }^{30}$ There are two classifications of these drug transporters: The ATP-binding cassette (ABC) family and the solute carrier (SLC) family. P-glycoprotein (P-gp) is a member of the ABC family, and could be induced by various factors, including clinical drugs, environmental xenobiotics, and dietary compounds; ${ }^{31}$ which is known to be involved in the drug interactions. There are reports that genistein from soy inhibits the efflux of the P-gp substrates cimetidine ${ }^{32}$ and paclitaxel. ${ }^{33}$ The efflux of vinblastine in KB-V1 cells highly expressing $\mathrm{P}$-gp, and the P-gp substrate paclitaxel could be inhibited by genistein at some doses. ${ }^{34}$ In addition to the P-gp, interactions may occur through other drug transporters. So, DMEs and drug transporters play important roles in the absorption, distribution, metabolism, and the excretion (ADME) of the drugs, and are involved in the interactions that will affect the pharmacokinetics and pharmacodynamics of the drugs.

These pharmacokinetic interactions could be seen by assessing the pharmacokinetic parameters including the area under the curve $(A \cup C)$, maximum concentration $\left(C_{\max }\right)$, volume of distribution $(\mathrm{Vd})$, half-life $\left(t_{1 / 2}\right)$, and clearance. Nagashima et al. ${ }^{23}$ found that soybean increases the AUC of levodopa. Soybean also reduces the $A \cup C$ and $C_{\max }$ of losartan. ${ }^{35}$ These differences in pharmacokinetic parameters depend on the mechanism. Until now, there has been no summary to explain how soy isoflavones could affect the pharmacokinetic profile of a drug and the mechanisms involved. This is needed as a reference regarding the safety of using soy isoflavones as daily nutrients with the co-administration of the drugs.

\section{Methods}

This review is based on the literature collected from the internet through Google Scholar, Elsevier, PubMed, and NCBI, using the keywords soybean, soy products, soy isoflavones, soy drug interaction, isoflavone content, daidzein, genistein, isoflavone interaction, pharmacokinetic parameter, and the pharmacokinetic interaction. In total, 181 articles were collected, but only 99 articles were included based on the inclusion criteria. The inclusion criteria were articles with a publication year before 2000, containing a description of pharmacokinetic parameter values, describing interactions with soybeans, containing isoflavone content data, or related to isoflavones, soybeans, and pharmacokinetic interactions. The flowchart of the search is illustrated in Figure 1. 


\section{Soy isoflavones}

Isoflavones are bioactive metabolites and include a group of phytoestrogens. Isoflavones have structures like those of mammalian estrogens. The largest source of isoflavones is soybean. Soy isoflavones are present in 12 different isoforms, divided into four chemical forms: Acetylglucoside (acetylgenistin, acetylglycitin, acetyldaidzin), malonylglucoside (malonylgenistin, malonyldaidzin, malonylglycitin), glucoside (genistein, daidzin, and glycitin), and aglycone (genistein, daidzein, and glycitein). ${ }^{36}$ After the metabolism process in the human gut, glucoside isoflavones become aglycones through the effect of gastrointestinal enzymes. ${ }^{5}$ Genistein, daidzein, and glycitein comprise approximately $50 \%, 40 \%$, and $10 \%$ of the isoflavones in soybean. ${ }^{37}$ The isoflavone content is influenced by several factors; in this article, we summarize the content of genistein, daidzein, and glycitein in soybeans, as seen in Table 1. ${ }^{37-47}$ The amount of isoflavones is in the order genistein $>$ daidzein > glycitein, and the content of the glycoside form is lower than that of the aglycone form; differences arise based on the variety, location of the production, humidity etc. ${ }^{38}$ Sources of isoflavones include soy products such as traditional soy

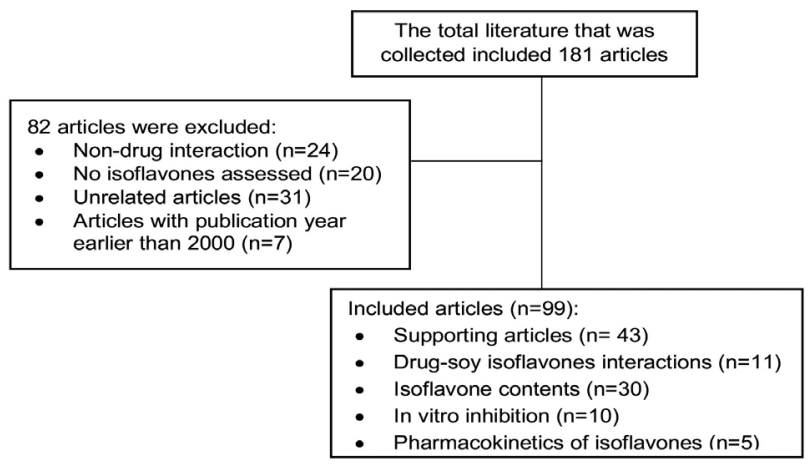

Figure 1. Flow chart of the literature review foods (such as tofu and soy milk), isolated soy protein, soybean paste, soy flakes, soy flour, fermented soybean products (such as tempeh, miso, and natto), and soy sauce. ${ }^{39}$

In each type of soybean product containing different soy isoflavones, we summarize the isoflavone content focusing only on the aglycone form, (i.e., genistein, daidzein, and glycitein in various soy products from the several studies, presented in Table 2). ${ }^{48-62}$ It appears that soy tablets commercially contain the highest levels of isoflavones, because soy tablets are usually used as additional nutrients so the soy isoflavone content is adjusted to nutritional requirements. Of the soy products shown Table 2, sufu has the highest content compared to others. Sufu is a traditional food from China, and it is made of fermented soybean curd. ${ }^{48}$ Other fermented foods that also have high soy isoflavones content are natto, tempeh, and miso. The fermentation process influences the isoflavone content. Fermentation can increase aglycone isoflavones from black soybean pulp ${ }^{49}$ in tempeh and tofu. ${ }^{50,51}$ Another study reported a $75 \%$ increase in aglycone isoflavones in soybean flour after fermentation. ${ }^{52}$ The fermentation process is also influenced by the several factors such as time and temperature. ${ }^{53,54}$

The differences in the isoflavone content of soybean products also leads to variations in the pharmacokinetic profile of isoflavones, as presented in Table 3. There are variations in the different levels, caused by many factors, [i.e., differences in the test subjects used (human, rats, or mice), variations in the age, the hydrolysis process of glycosides by the gut bacteria or gut wall enzymes, uptake, ethnicity, etc]. ${ }^{44}$ The content of daidzein and genistein in soy products depends on the raw material and the conditions while processing, Faughnan et al. ${ }^{63}$ found that urinary recovery of equol from tempeh is higher than the soymilk, although the solid food matrix and fermentation may increase the production of equol. Equol is a metabolite of daidzein produced by the intestinal bacteria; the level of equol production has been linked to the consumption, and the content

Table 1. Summary of isoflavone contents in soybean

\begin{tabular}{|c|c|c|c|c|c|c|c|}
\hline Sample & Genistein & Daidzein & Glycitein & Genistein & Daidzin & Glycitin & Reference \\
\hline Soybean extract & $36.55 \mu \mathrm{g} / \mathrm{g}$ & $88.87 \mu g / g$ & $34.42 \mu \mathrm{g} / \mathrm{g}$ & - & - & - & 40 \\
\hline Soybean extract & $1260 \mu \mathrm{g} / \mathrm{g}$ & $849 \mu \mathrm{g} / \mathrm{g}$ & $174 \mu \mathrm{g} / \mathrm{g}$ & - & - & - & 41 \\
\hline Soybean & $0.126 \mu \mathrm{g} / \mathrm{g}$ & $0.71 \mu \mathrm{g} / \mathrm{g}$ & - & - & - & - & 37 \\
\hline Soybean & $330 \mu \mathrm{g} / \mathrm{g}$ & $100 \mu \mathrm{g} / \mathrm{g}$ & $50 \mu \mathrm{g} / \mathrm{g}$ & $100 \mu \mathrm{g} / \mathrm{g}$ & $69 \mu \mathrm{g} / \mathrm{g}$ & - & 42 \\
\hline Soybean (market origin) & $2971 \mu \mathrm{g} / \mathrm{g}$ & $2579 \mu \mathrm{g} / \mathrm{g}$ & - & - & - & - & 43 \\
\hline Soy sprout & $232 \mu \mathrm{g} / \mathrm{g}$ & $177 \mu \mathrm{g} / \mathrm{g}$ & - & & & & 43 \\
\hline Soy flour & - & - & - & $700 \mu \mathrm{g} / \mathrm{g}$ & $620 \mu \mathrm{g} / \mathrm{g}$ & & 44 \\
\hline Soybean & $42 \mu \mathrm{g} / \mathrm{g}$ & $47.8 \mu \mathrm{g} / \mathrm{g}$ & $2.7 \mu \mathrm{g} / \mathrm{g}$ & - & - & - & 45 \\
\hline
\end{tabular}


of the isoflavone daidzein. The solid food matrix of tempeh may protect isoflavones from degradation, so they could reach the large intestine and metabolized into equol by the gut bacteria. This indicates that tempeh contains more daidzein than soymilk. Information about pharmacokinetics is very important to evaluate the safety and understand the efficacy. For example, from the $t_{1 / 2}$, we could predict that how long isoflavones are still present in the body, so that its consumption time could be regulated by the medication.

It turns out that not only isoflavone tablets are high in isoflavones, but daily food processed from the soy also contains quite high levels of isoflavones, and may interact if taken together with certain drugs. Thus, there is a need for careful monitoring. An assessment of the pharmacokinetic profile of several other processed soybean products needs to be done, for example tofu, to obtain more information.

The mechanism of drug-isoflavone pharmacokinetic interactions

Drug interactions not only occur between drugs, but also occur between drugs and herbal or natural compounds, such as isoflavones. Isoflavones are a component of dietary foods or herbal supplements, so there is a possibility of long-term exposure together with the drugs. This simultaneous use may lead to the drug-isoflavone interactions. This is supported by Laurenzana et al. ${ }^{64}$, who found that the content of natural materials such as flavones, isoflavones, and tangeretin affects the activity of human CYP enzymes when given orally together with the drugs. These changes in ADME will certainly affect the pharmacokinetic parameters of the drugs, because of the interactions with DMEs and interaction with the drug transporters.

In this article, the pharmacokinetic interactions between isoflavones and some drugs and their mechanisms of interaction have been summarized, focusing on the enzymes and drug transporters, as shown in Table 4. It has been reported that the co-administration of soy isoflavones (genistein or daidzein), soy tablets, or soybean extract with drugs results in changes in the pharmacokinetic parameters of the drug, which indicates an interaction. These effects include the changes in the AUC, $C_{\text {max' }}$ and the clearance. These changes may be either an increase or

Table 2. Isoflavone contents of soybean products

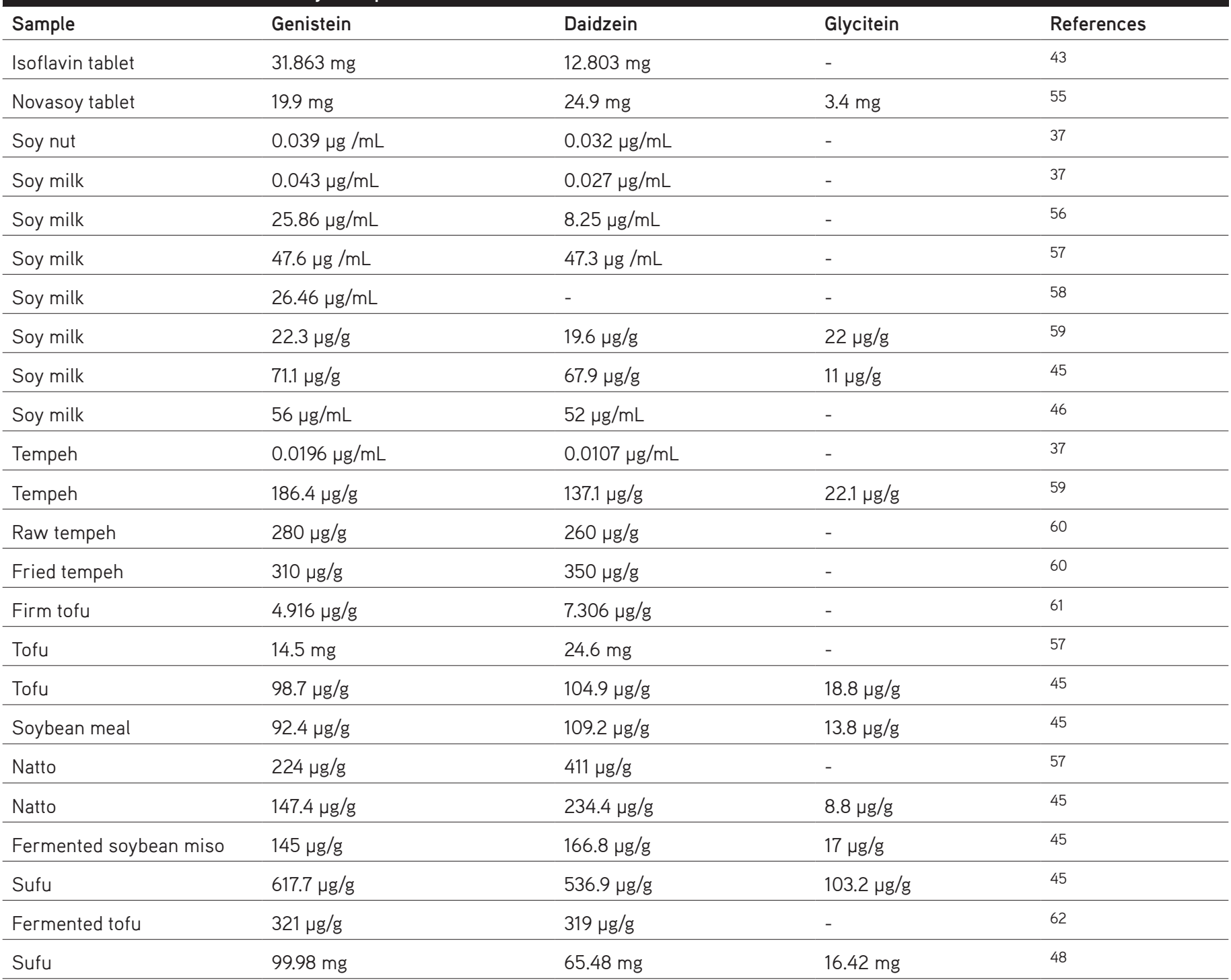


a decrease in the pharmacokinetic parameters, depending on the mechanism. The mechanisms that will be discussed here involve enzymes and drug transporters.

\section{Effects of soy isoflavones on drug metabolizing enzymes}

Soybeans influence the metabolism of the drugs, and affect ADME through the interactions with phase-I or phase-II DMEs. The enzymes involved in phase-I metabolism are the CYP450 families, while the enzymes involved in phaseII metabolism are sulfotransferases, uridine diphosphate glucuronosyltransferases (UDPGT/UGTs), N-acetyl transferases (UDPGT/UGTs), glutathione-S-transferases, and methyltransferases. ${ }^{25}$

\section{Phase-I metabolism enzymes}

CYP450 are the main group of enzymes that catalyze the oxidative biotransformation of the drugs and other lipophilic xenobiotics. ${ }^{27}$ The enzymes involved in the drugs metabolism are CYP1A2, CYP2C9, CYP2C19, CYP2D6, and CYP3A4. ${ }^{26}$ The enzymes that are influenced by soy isoflavone are discussed below based on the pharmacokinetic interaction mechanism of some drugs (Table 4). To support the discussion, we have summarized the inhibitory effect of soy isoflavones on CYP enzymes in Table 5.

\section{CYP2C9}

Pharmacokinetic interactions may occur through the inhibition or induction of DMEs. Around 15\% of all drug biotransformation is metabolized by the CYP2C9. ${ }^{78}$ An interaction between celecoxib and genistein has been reported; ${ }^{65}$ as shown in Table 4, there is an increase in $C_{\max }$ and $A U C$ is almost 2.7 times higher than celecoxib alone, because of the inhibition of the CYP2C9 enzyme by genistein. Thus, the metabolism of celecoxib is reduced, clearance also decreases, and celecoxib accumulates in the body. This mechanism is also in line with the results of Kopecna-Zapletalova et al. ${ }^{77}$ based on in vitro studies (Table 5) showing that genistein may inhibit CYP2C9 at doses of $35.96 \mathrm{mmol} / \mathrm{L}$ and $100 \mu \mathrm{M}$. ${ }^{65}$ The flavone structure of genistein (4,5,5,7-trihydroxyisoflavone) may suppress CYP2C9 by interacting with the active site of CYP2C9. ${ }^{79}$

\section{CYP1A2}

The same effect was also seen by Peng et al. ${ }^{66}$ when theophylline was given with soy isoflavones such as daidzein at a dose of $200 \mathrm{mg}$ twice a day to healthy volunteers. There was an increase in the $A U C$ and $C_{\max }$. Theophylline is mainly excreted through the hepatic metabolism pathway, and CYP1A2 catalyzes all these pathways; thus, the inhibition of CYP1A2 will inhibit the metabolism of this drug. This is also related to the

\begin{tabular}{|c|c|c|c|c|c|c|c|c|}
\hline Sample & Isoflavones & $\mathrm{C}_{\max }$ & $t_{\max }$ & $t_{1 / 2}$ & AUC & $\mathrm{Vd} / \mathrm{F}$ & $\mathrm{Cl} / \mathrm{F}$ & References \\
\hline Soy milk & Daidzein & $\begin{array}{l}2.19 \mu \mathrm{mol} / \mathrm{L} . \mathrm{mg} \\
\text { dose }\end{array}$ & $6.1 \mathrm{~h}$ & $8 \mathrm{~h}$ & $\begin{array}{l}22.09 \mu \mathrm{mol} . \mathrm{h} / \mathrm{L} \mathrm{mg} \\
\text { dose }\end{array}$ & 1.53 L/kg & $8.47 \mathrm{~L} / \mathrm{h}$ & 59 \\
\hline Tempeh & Daidzein & $\begin{array}{l}2.33 \mu \mathrm{mol} / \mathrm{L} . \mathrm{mg} \\
\text { dose }\end{array}$ & $8.4 \mathrm{~h}$ & $9.4 \mathrm{~h}$ & $\begin{array}{l}15.28 \mu \mathrm{mol} . \mathrm{h} / \mathrm{L} \mathrm{mg} \\
\text { dose }\end{array}$ & $2.07 \mathrm{~L} / \mathrm{kg}$ & 9.86 L/h & 59 \\
\hline Soy beverage & Daidzein & $96.31 \mathrm{ng} / \mathrm{mL}$ & $5.92 \mathrm{~h}$ & $7.68 \mathrm{~h}$ & $11.50 \mathrm{ng} . \mathrm{h} / \mathrm{mL}$ & - & - & 44 \\
\hline $\begin{array}{l}\text { Soy extract } \\
\text { capsule }\end{array}$ & Daidzein & $96.02 \mathrm{ng} / \mathrm{mL}$ & $6.25 \mathrm{~h}$ & $6.67 \mathrm{~h}$ & 1211.93 ng.h/mL & - & - & 44 \\
\hline $\begin{array}{l}\text { Soy isoflavones } \\
\text { (isogen) }\end{array}$ & Daidzein & $230 \mathrm{ng} / \mathrm{mL}$ & $3.78 \mathrm{~h}$ & $9.75 \mathrm{~h}$ & 2629 ng.h/mL & $211.4 \mathrm{~L}$ & $12.2 \mathrm{~L} / \mathrm{h}$ & 46 \\
\hline $\begin{array}{l}\text { Fermented } \\
\text { soybean }\end{array}$ & Daidzein & $214 \mathrm{ng} / \mathrm{mL}$ & $2.88 \mathrm{~h}$ & $9.54 \mathrm{~h}$ & 2594 ng.h/mL & $295.4 \mathrm{~L}$ & $12.9 \mathrm{~L} / \mathrm{h}$ & 46 \\
\hline Soymilk & Daidzein & $211.2 \mathrm{ng} / \mathrm{mL}$ & $3.71 \mathrm{~h}$ & $5.92 \mathrm{~h}$ & 2101 ng.h/mL & $131.4 \mathrm{~L}$ & $19 \mathrm{~L} / \mathrm{h}$ & 46 \\
\hline Soymilk & Genistein & $\begin{array}{l}4.07 \mu \mathrm{mol} / \mathrm{L} . \mathrm{mg} \\
\text { dose }\end{array}$ & $5.6 \mathrm{~h}$ & $9.9 \mathrm{~h}$ & $\begin{array}{l}50.01 \mu \mathrm{mol} . \mathrm{h} / \mathrm{L} \mathrm{mg} \\
\text { dose }\end{array}$ & $0.72 \mathrm{~L} / \mathrm{kg}$ & $3.31 \mathrm{~L} / \mathrm{h}$ & 59 \\
\hline Soymilk & Genistein & $231.1 \mathrm{ng} / \mathrm{mL}$ & $4.86 \mathrm{~h}$ & $5.64 \mathrm{~h}$ & 2326 ng.h/mL & $104 \mathrm{~L}$ & 13.5 L/h & 46 \\
\hline Tempeh & Genistein & $\begin{array}{l}2.35 \mu \mathrm{mol} / \mathrm{L} . \mathrm{mg} \\
\text { dose }\end{array}$ & $7.2 \mathrm{~h}$ & $9.4 \mathrm{~h}$ & $\begin{array}{l}32.28 \mu \mathrm{mol} . \mathrm{h} / \mathrm{L} \mathrm{mg} \\
\text { dose }\end{array}$ & 1.12 L/kg & $6.58 \mathrm{~L} / \mathrm{h}$ & 59 \\
\hline Soy beverage & Genistein & $116.37 \mathrm{ng} / \mathrm{mL}$ & $5.75 \mathrm{~h}$ & $7.61 \mathrm{~h}$ & 1437.23 ng. h/mL & - & - & 44 \\
\hline $\begin{array}{l}\text { Soy extract } \\
\text { capsule }\end{array}$ & Genistein & 261.84 ng/mL & $7 \mathrm{~h}$ & $7.96 \mathrm{~h}$ & 3259.54 ng. h/mL & - & - & 44 \\
\hline $\begin{array}{l}\text { Soy isoflavones } \\
\text { (isogen) }\end{array}$ & Genistein & $160 \mathrm{ng} / \mathrm{mL}$ & $4.67 \mathrm{~h}$ & $8.53 \mathrm{~h}$ & 2356 ng.h/mL & $226 \mathrm{~L}$ & $15.1 \mathrm{~L} / \mathrm{h}$ & 46 \\
\hline $\begin{array}{l}\text { Fermented } \\
\text { soybean }\end{array}$ & Genistein & $195.7 \mathrm{ng} / \mathrm{mL}$ & $3.5 \mathrm{~h}$ & $8.22 \mathrm{~h}$ & 2279 ng.h/mL & $347 \mathrm{~L}$ & $17.4 \mathrm{~L} / \mathrm{h}$ & 46 \\
\hline
\end{tabular}

$C_{\max }:$ Maximum concentration, $\mathrm{t}_{\max }:$ Time-to-maximum, $\mathrm{t}_{1 / 2}$ : Half-life, AUC: Area under the curve, Vd: Volume of distribution 


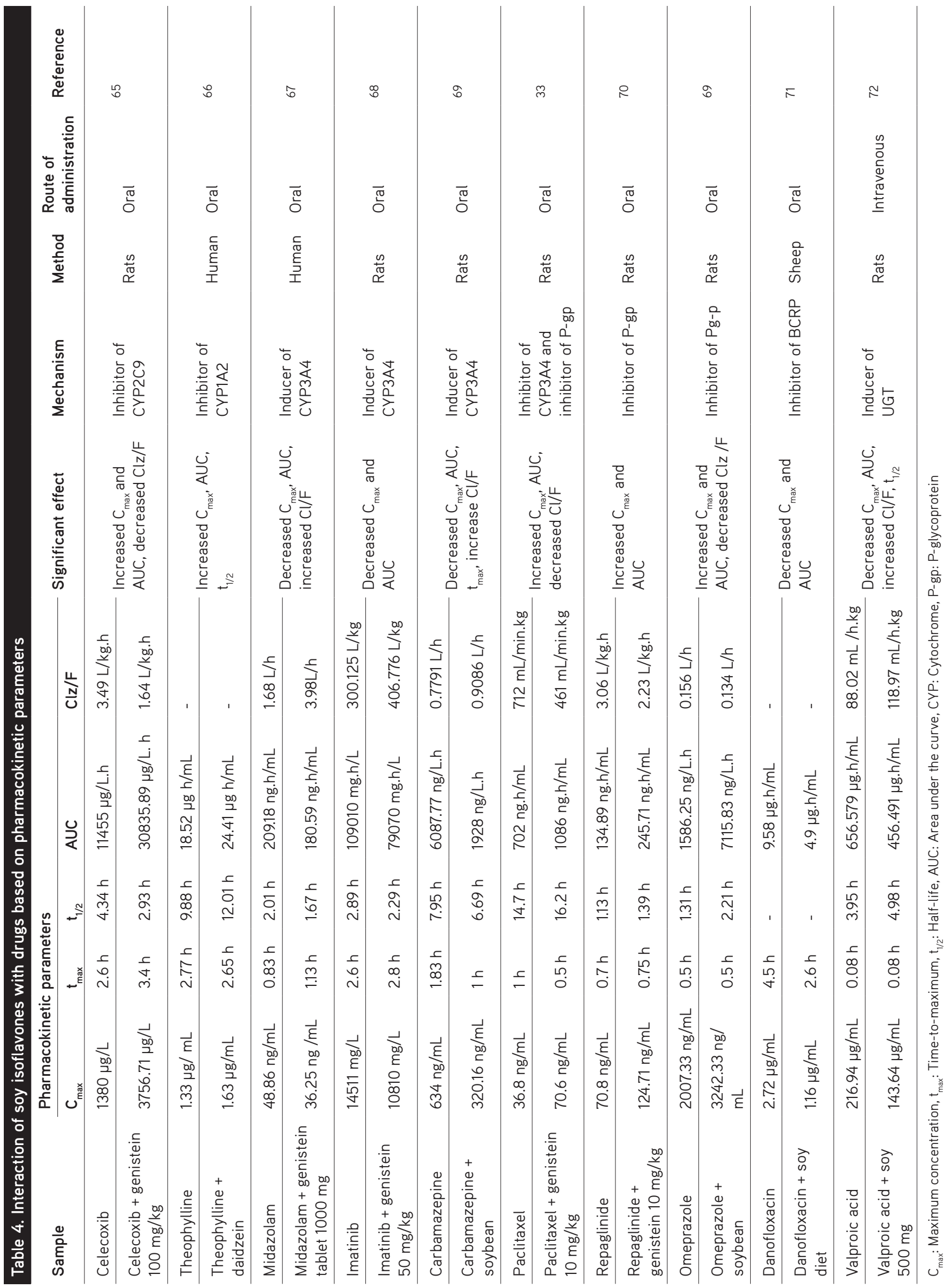


results of Anderson et al. ${ }^{76}$ who showed that soybean extract inhibits the CYP1A2 enzyme in vitro; one of the isoflavones contained in soy extract is daidzein.

\section{CYP3A4}

Inhibition of CYP3A4 will increase the drug levels, as shown by Li and Choi. ${ }^{33}$ In vivo, genistein may increase the value of $A U C$ and $C_{\max }$ of paclitaxel through the inhibition of CYP3A4; this is also supported by in vitro studies. It has been widely reported that genistein from soybean inhibits CYP3A4. ${ }^{28,76,77}$ In vitro studies have reported that genistein inhibits CYP3A4 at a concentration of $0.5 \mathrm{mM} /$ well, supported by KopecnaZapletalova et al. ${ }^{77}$ from 2016 showing that genistein may inhibit CYP3A4 at a concentration of $23.25 \mathrm{mM}$. Another trial using different cells, namely $V_{79}$ cells, showed the inhibitory activity of genistein on CYP3A4. ${ }^{75}$ The inhibitory effect of isoflavones on CYP3A4 is classified as moderate inhibition and is noncompetitive. ${ }^{77}$

In addition to the inhibitory effect described above, some studies show that the mechanism of isoflavones also may alter the pharmacokinetics of drugs by the induction of enzymes. This may decrease the $A U C$ and $C_{\text {max }}$ and increase clearance. Studies by Xiao et al. ${ }^{67}$ showed there is a change in the value of midazolam pharmacokinetic parameters after the patients were given genistein tablets $(1000 \mathrm{mg}$ ) for 14 days; the same thing was also found for imatinib ${ }^{80}$ and carbamazepine. ${ }^{69}$ Midazolam and imatinib are primarily metabolized by CYP3A4 after oral administration. ${ }^{67}$ Imatinib is metabolized into $\mathrm{N}$-desmethyl imatinib by CYP3A $4^{80,81}$ and is a prodrug. This means that there is a different mechanism for the prodrug. Prodrugs are activated by a CYP, so it is important to know if metabolism or the activation of enzymes may alter CYP activity. ${ }^{82}$ Genistein increases the $\mathrm{C}_{\max }$ and $\mathrm{AUC}$ of $\mathrm{N}$-desmethyl imatinib by the induction of CYP3A4. In the future, to clarify the mechanism, it will be necessary to carry out a deeper investigation related to the effect of soy isoflavones on prodrugs.

Induction of xenobiotic-mediated CYP3A genes in humans is known to be regulated by pregnane $X$ receptors (PXR), constitutive and immune receptors, glucocorticoid receptors, and other receptors. ${ }^{83}$ PXR is the main regulator of xenobioticinduced CYP3A gene expression. Previous research has found that genistein may significantly activate the human PXR, and induce the human CYP3A4 luciferase reporter activity. ${ }^{84}$ According to this study, we consider that genistein acts as an inducer of CYP3A4 in humans. However, the ${ }_{\text {CYP3A4 }}$ induction mechanism is contrary to in-vitro studies (Table 4) because many studies report that soy, and its isoflavones have an inhibitory effect rather than induction, so there is no in vivo/ in vitro correlation related to the effect of soybean on CYP3A4.

According to Cheng et al. ${ }^{48}$ soybean contains $42 \mu \mathrm{g} / \mathrm{g}$ genistein and $4.78 \mu \mathrm{g} / \mathrm{g}$ daidzein, while some have reported extracts containing and $1260 \mu \mathrm{g} / \mathrm{g}$ genistein and $849 \mu \mathrm{g} / \mathrm{g}$ daidzein, ${ }^{41}$ or $36.55 \mu \mathrm{g} / \mathrm{g}$ genistein and $88.87 \mu \mathrm{g} / \mathrm{g}$ daidzein. ${ }^{40}$ These variations in the content may be caused by the differences in the soybean variety assessed, the location of growth, plant age, etc. Other than that, processed soybean foods such as tofu, tempeh, soy milk, natto, miso, and sufu also have variable contents, which could be seen in Table 3. For example, fried

Table 5. Summary of the inhibitory effects of soy isoflavones on CYP enzymes

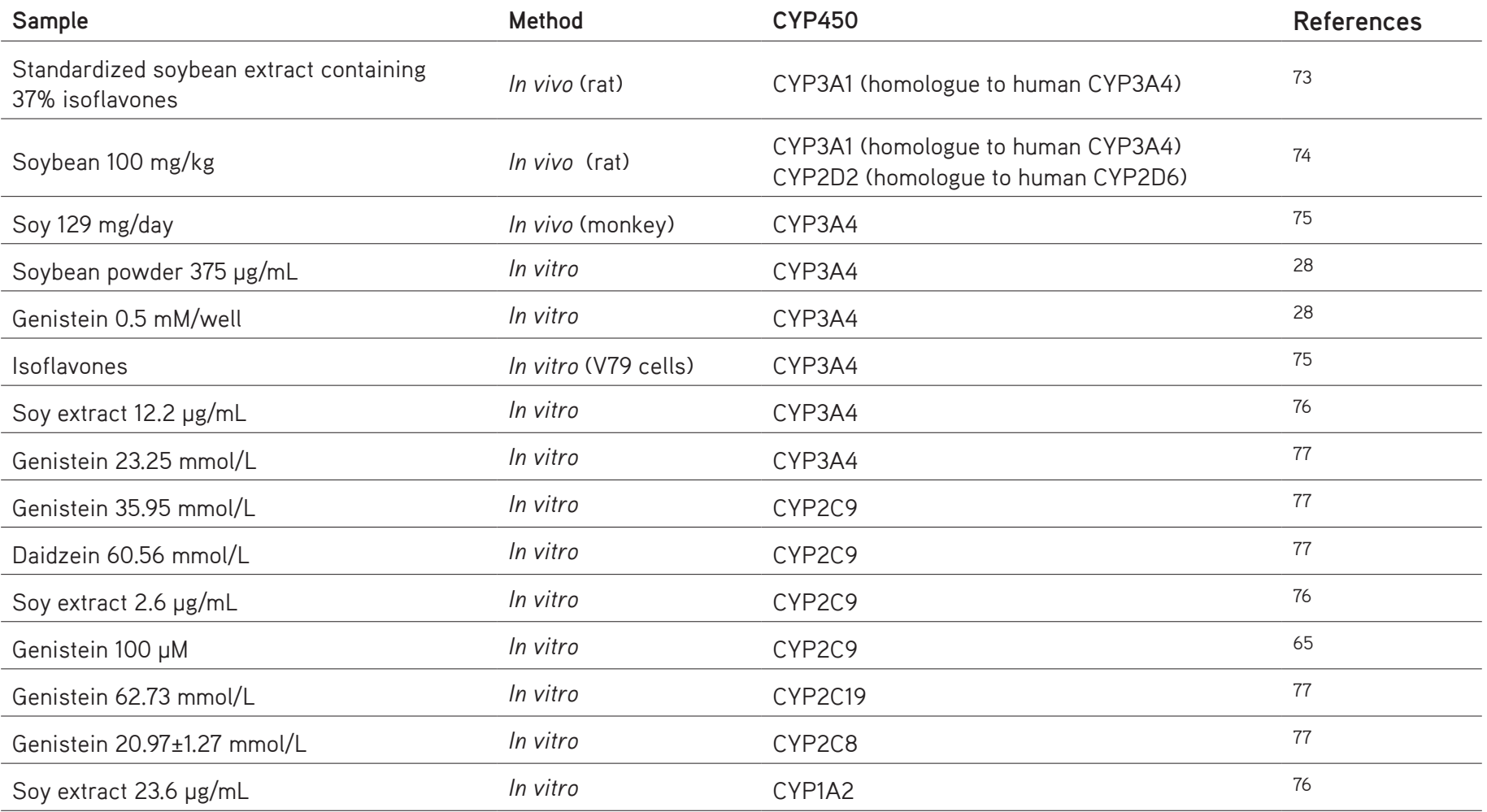

CYP450: Cytochrome P450 
tempeh contains $310 \mu \mathrm{g} / \mathrm{g}$ genistein and $350 \mu \mathrm{g} / \mathrm{g}$ daidzein. ${ }^{60} \mathrm{In}$ natto, the level of genistein is $224 \mu \mathrm{g} / \mathrm{g}$ and that of daidzein is $411 \mu \mathrm{g} / \mathrm{g}^{57}$, but soymilk has a lower content of $56 \mu \mathrm{g} / \mathrm{mL}$ and 52 $\mu \mathrm{g} / \mathrm{mL}$, respectively. ${ }^{46}$ When linked with experimental data in vitro from the various studies, it appears that soybean extract may inhibit the CYP3A4 enzyme at a concentration of $12.2 \mu \mathrm{g} /$ $\mathrm{mL}$, CYP2C9 at $2.6 \mu \mathrm{g} / \mathrm{mL}$, and CYP1A2 at $23.6 \mu \mathrm{g} / \mathrm{mL} .{ }^{76}$ This means that consuming 1 gram of soybean extract may influence these enzymes. The same thing is also the case with soybeans and soybean products, because the content of genistein and daidzein (shown in Table 3) in each gram exceeds the inhibitory dose reported by Kopecna-Zapletalova et al. ${ }^{77}$ However, further in vivo studies in human subjects need to be performed, as in vivo studies have only been conducted on mice with soybean doses that inhibit CYP3A1 (the homologue to CYP3A4 in humans), (i.e., $100 \mathrm{mg} / \mathrm{kg}$ ). ${ }^{74}$ If simplified, the dose is equivalent to $100 \mu \mathrm{g} / \mathrm{g}$, so based on this the consumption of soymilk, tofu, soybeans could be said to be safe, but again further research is needed to obtain more accurate results.

\section{Phase-Il metabolism enzymes}

\section{Uridine diphosphate glucuronosyltransferases}

Soybean increases the phase-II metabolism of drugs to increase the detoxification and clearance of potentially carcinogenic intermediaries. The results of Marahatta et al..$^{72}$ report that the administration of $500 \mathrm{mg}$ for 5 days could affect valproic acid (VPA) in terms of its pharmacokinetic parameters. Specifically, the $\mathrm{C}_{\max }$ decreased by $65 \%$, but time-to-maximum $\left(t_{\max }\right)$ was not significantly different. AUC decreased by $69 \%$. There were significant differences in $C_{\text {max }} t_{1 / 2}, A U C$, and clearance between the treatment and control groups. ${ }^{72}$ Soybean contributes to VPA excretion, which is very effective as it increases VPA glucuronidation. Valproate glucuronide is the main metabolite of VPA in urine and is metabolized by UGT1A3, UGT1A4, UGT1A6, UGT1A8, UGT1A9, UGT1A10, UGT2B7, and UGT2B15. The metabolism and elimination of VPA is affected by glucuronidation, especially by uridine 59-diphosphateglucuronosyltransferase. Similarly, previous studies have shown that soy induces the UGT enzyme, an important component of glucuronidation. ${ }^{85}$ Daidzein may stimulate glucuronidation. ${ }^{86}$ Similarly, genistein has been reported to induce UGT activity. ${ }^{87}$ The inhibition or induction of important enzymes for drugs that require therapeutic drug monitoring and food-drug interactions depend on the therapeutic index of each drug. ${ }^{.2}$

\section{Effects of soy isoflavones on drug transporters}

Drug transporters have an important role in the ADME of drugs and xenobiotics. ${ }^{88}$ Drug transporters are also related to disposition of drug and drug interactions. ${ }^{89}$ Drug transporters are classified as uptake and efflux transporters. Uptake transporters play a role in facilitating the translocation of drugs into cells such as organic anion transporting polypeptides (OATP; SLCO) ${ }^{90}$, organic anion transporters (OAT; SLC22A) ${ }^{91}$, and organic cation transporters (OCT; SLC22A) ${ }^{92}$, while efflux transporters transfer or remove drugs from the intracell to the extra cell, for example the ABC group and SLC transporters. The $A B C$ family includes transporters for the elimination of drugs likes P-gp [multidrug resistance protein 1 (MDR1); ABCB1], certain members of the multidrug resistance-associated protein (MRP; $A B C C)$ family, and breast cancer resistance protein [(BCRP); $A B C G]$. These drug transporters are expressed in the intestine or liver, two main locations that affect how much drug will enter the body after the administration of an oral dose. Thus, the effect of isoflavones on drug transporters is important because it will affect the pharmacokinetic profile of a drug. ${ }^{93} \mathrm{As}$ shown in Table 4, the pharmacokinetic interaction mechanisms of some drugs occur only through efflux transporters.

\section{Efflux drug transporters}

\section{P-glycoprotein}

P-gp is a product of the MDR1 gene, which is an efflux transporter that is widely studied and known for its ability to limit the entry of drugs into various organ compartments. P-gp functions as an efflux pump, such that it facilitates the transfer of intracellular drugs to the extracellular space. ${ }^{26}$ Genistein may influence the administration of the drugs by modulating efflux proteins such as MDR1 and P-gp. P-gp is expressed mainly in the apical membrane of the intestine. MDR1 has been reported to increase the elimination of drugs in the intestinal lumen. ${ }^{34}$ This mechanism is shown in Figure 2. Genistein inhibits P-gp and causes pharmacokinetic interactions with repaglinide at a genistein concentration of $10 \mathrm{mg} / \mathrm{kg}$, characterized by an increase in the repaglinide $A U C$ of $53 \%$ and $C_{\max }$ by $36 \% .^{70}$ Genistein affects P-gp by increasing intestinal absorption. Li and Choi. ${ }^{33}$ found an increase in the paclitaxel plasma concentration with a mechanism of P-gp inhibition, similar to what was also found with midazolam. ${ }^{69}$ To confirm, Li et al. ${ }^{54}$ tested Caco2 cells and IEC-6 cells to investigate further repaglinide absorption in human cells and in mice, resulting in significantly increased intracellular repaglinide accumulation with genistein administration. ${ }^{70}$ This means that P-gp transporters, which are supposed to carry drugs to the extracellular are blocked by genistein, resulting in the intracellular accumulation of repaglinide.

The mechanism by which genistein inhibits P-gp was revealed by molecular docking studies. The basic structure of P-gp includes four main core regions, with two nucleotide-binding

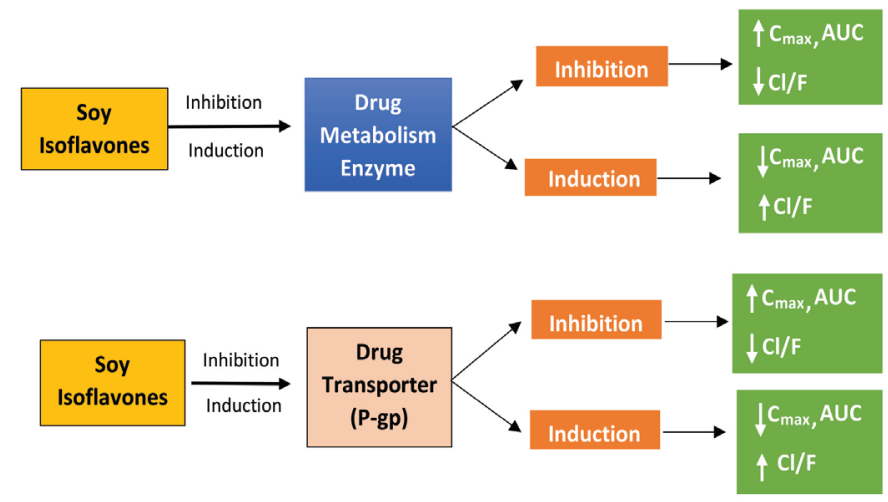

Figure 2. Mechanisms of pharmacokinetic interactions between drugs and soy isoflavones (based on Table 4)

$\mathrm{C}_{\text {max }}$ : Maximum concentration, AUC: Area under the curve, P-gp: P-glycoprotein, $\mathrm{CL} / \mathrm{F}$ : Oral clearance 
domains (NBD) located in the cytoplasm and two hydrophobic transmembrane domains (TMD). ${ }^{94}$ The TMD serve as a channel to facilitate drug transport, whereas the NBD located in the cytoplasm have binding sites for ATP, used as the energy supply for drug transport. ${ }^{95}$ 6COV was chosen as a P-gp molecule with a three-dimensional structure combined with NBD simulation; it was found that genistein has a certain binding affinity for NBD and shares several binding sites with ATP in the corresponding functional area, which affects the energy supply when the drug is transported by P-gp. This is what causes the inhibition of the efflux function of P-gp. ${ }^{70}$

\section{$B C R P$}

Drug interactions that lead to the inhibition of efflux transporters can cause changes in the pharmacokinetics of the drug. For example, in the case of BCRP, several drugs are secreted into milk, such as danofloxacin as shown in a study performed in sheep given a soy diet to see its effect on drug levels in milk. A change was observed in the pharmacokinetic parameters of danofloxacin, namely a $50 \%$ decrease in $\mathrm{C}_{\max }$ and AUC. ${ }^{71} B C R P$ inhibitors administered with drugs that are substrates of the transporter could have effects on in vivo ADME, as well as the presence of drugs in milk. ${ }^{96,97}$ A soy diet contains daidzein and genistein, which are BCRP inhibitors.98,99

From what has been discussed above, we could see that the pharmacokinetic interaction of soy isoflavones with drugs occurs through the several mechanisms, (i.e., through DMEs or drug transporters). These interactions will affect the bioavailability of drugs in the blood. The mechanisms are summarized and illustrated in Figure 2.

\section{CONCLUSION}

Soybeans are a good source of isoflavones. The isoflavone content of soybean is mainly in the aglycone form as daidzein, genistein, and glycitein. Soybean products also contain variable levels of isoflavones. Co-administration of soy isoflavones with the drugs may cause pharmacokinetic interactions. These interactions may cause changes in the AUC, $C_{\text {max }} t_{\text {max }}$, and $t_{1 / 2}$ of the drugs. These interactions occur through mechanisms related to the inhibition/induction of DMEs, namely CYP3A4, CYP2C9, CYP1A2, and UGT or the inhibition/induction of drug transporters, such as P-gp and BCRP. Thus, the consumption of soy, soy isoflavones, or soy products together with the drugs needs to be considered because this diet may affect the efficacy of the drugs. Furthermore, the timing and consumption of soy isoflavones with the drugs should be monitored.

Conflict of interest: No conflict of interest was declared by the authors. The authors alone are responsible for the content and writing of this article.

\section{REFERENCES}

1. Terzic D, Popovic V, Tatic M. Soybean area, yield and production. Ecol Mov Novi Sad. 2018;135-143.
2. Zaheer K, Humayoun Akhtar M. An updated review of dietary isoflavones: Nutrition, processing, bioavailability and impacts on human health. Crit Rev Food Sci Nutr. 2015;57:1280-1293.

3. Cheng PF, Chen JJ, Zhou XY, Ren YF, Huang W, Zhou JJ, Xie P. Do soy isoflavones improve cognitive function in postmenopausal women? A meta-analysis. Menopause. 2015;22:198-206.

4. Larkin T, Price WE, Astheimer L. The key importance of soy isoflavone bioavailability to understanding health benefits. Crit Rev Food Sci Nutr. 2008;48:538-552.

5. Tsourounis C. Clinical effects of phytoestrogens. Clin Obstet Gynecol. 2001;44:836-842.

6. Teekachunhatean S, Hanprasertpong N, Teekachunhatean T. Factors affecting isoflavone content in soybean seeds grown in Thailand. Int $\mathrm{J}$ Agron. 2013;2013:1-11.

7. Ahsan M, Mallick AK. The effect of soy isoflavones on the menopause rating scale scoring in perimenopausal and postmenopausal women: $A$ pilot study. J Clin Diagnostic Res. 2017;11:13-16.

8. Agostoni C, Bresson J, Tait S, Flynn A, Golly I, Korhinen H. Scientific Opinion on the substantiation of health claims related to soy isoflavones and maintenance of bone mineral density (ID 1655) and reduction of vasomotor symptoms associated with menopause. EFSA J. 2012;10:2847.

9. Chi XX, Zhang T. Isoflavone intake inhibits the development of 7,12 dimethylbenz(a)anthracene(DMBA) induced mammary tumors in normal and ovariectomized rats. J Clin Biochem Nutr. 2013;54:31-38.

10. Mace TA, Ware MB, King SA, Loftus S, Farren MR, McMichael E, Scoville S, Geraghty C, Young G, Carson WE 3rd, Clinton SK, Lesinski GB. Soy isoflavones and their metabolites modulate cytokine-induced natural killer cell function. Sci Rep. 2019;9:5068.

11. Zhang X, Gao YT, Yang G, Li H, Cai Q, Xiang YB, Ji BT, Franke AA, Zheng W, Shu XO. Urinary isoflavonoids and risk of coronary heart disease. Int J Epidemiol. 2012;41:1367-1375.

12. Yoon GA, Park S. Antioxidant action of soy isoflavones on oxidative stress and antioxidant enzyme activities in exercised rats. Nutr Res Pract. 2014;8:618-624.

13. Sahin I, Bilir B, Ali S, Sahin K, Kucuk O. Soy isoflavones in integrative oncology: increased efficacy and decreased toxicity of cancer therapy. Integr Cancer Ther. 2019:1-11.

14. Mizushina Y, Shiomi K, Kuriyama I, Takahashi Y, Yoshida H. Inhibitory effects of a major soy isoflavone, genistein, on human DNA topoisomerase II activity and cancer cell proliferation. Int J Oncol. 2013;43:1117-1124.

15. He F-J, Chen J-Q. Consumption of soybean, soy foods, soy isoflavones and breast cancer incidence: Differences between Chinese women and women in Western countries and possible mechanisms. Food Sci Hum Wellness. 2013;2:146-161.

16. Fonseca ND, Villar MPM, Donangelo CM, Perrone D. Isoflavones and soyasaponins in soy infant formulas in Brazil: Profile and estimated consumption. Food Chem. 2014;143:492-498.

17. Klein $C B$, King AA. Genistein genotoxicity: critical considerations of in vitro exposure dose. Toxicol Appl Pharmacol. 2007;224:1-11.

18. Rizzo G, Baroni L. Soy, soy foods and their role in vegetarian diets. Nutrients. 2018;10:1-51.

19. U.S. Soybean Export Council. Recommended Soy Intakes. www.ussec. org. 2020:1-5. 
20. Varma M V, Pang SK, Isoherranen N, Zhao P. Dealing with the complex drug-drug interactions: Towards mechanistic models Manthena. Biopharm Drug Dispos. 2015 36:71-92.

21. Cambria-Kiely JA. Effect of soy milk on warfarin efficacy. Ann Pharmacother. 2002;36:1893-1896.

22. Chen J, Halls SC, Alfaro JF, Zhou Z, Hu M. Potential beneficial metabolic interactions between tamoxifen and isoflavones via cytochrome P450-mediated pathways in female rat liver microsomes. Pharm Res. 2004;21:2095-2104.

23. Nagashima $Y$, Kondo T, Sakata M, Koh J, Ito H. Effects of soybean ingestion on pharmacokinetics of levodopa and motor symptoms of Parkinson's disease - In relation to the effects of Mucuna pruriens. J Neurol Sci. 2016;361:229-234.

24. Temyingyong $\mathrm{N}$, Koonrungsesomboon N, Hanprasertpong $\mathrm{N}, \mathrm{Na}$ Takuathung M, Teekachunhatean S. Effect of short-course oral ciprofloxacin on isoflavone pharmacokinetics following soy milk ingestion in healthy postmenopausal women. Evidence-based Complement Altern Med. 2019;2019;1-10.

25. Taneja I, Raju KSR, Wahajuddin M. Dietary Isoflavones as modulators of drug metabolizing enzymes and transporters: effect on prescription medicines. Crit Rev Food Sci Nutr. 2015;56;1-69.

26. Tirona RG, Kim RB. Introduction to clinical pharmacology. Clin Transl Sci Princ Hum Res. 2017;20;365-388.

27. Zanger UM, Schwab M. Cytochrome P450 enzymes in drug metabolism: Regulation of gene expression, enzyme activities, and impact of genetic variation. Pharmacol Ther. 2013;138:103-141.

28. Foster BC, Vandenhoek S, Hana J, Krantis A, Akhtar MH, Bryan M, Budzinski JW, Ramputh A, Arnason JT. In vitro inhibition of human cytochrome P450-mediated metabolism of marker substrates by natural products. Phytomedicine. 2003;10:334-342.

29. Liu YT, Chen YH, Uramaru N, Lin AH, Yang HT, Lii CK, Yao HT. Soy isoflavones reduce acetaminophen-induced liver injury by inhibiting cytochrome P-450-mediated bioactivation and glutathione depletion and increasing urinary drug excretion in rats. J Funct Foods. 2016;26:135143.

30. Liu L,and Liu X. Contributions of drug transporters to blood-brain barriers. Adv Exp Med Bio. 2019;114:407-466.

31. Estudante M, Morais JG, Soveral G, Benet LZ. Intestinal drug transporters: An overview. Adv Drug Deliv Rev. 2013;65:1340-1356.

32. Taur JS, Rodriguez-Proteau R. Effects of dietary flavonoids on the transport of cimetidine via P-glycoprotein and cationic transporters in Caco-2 and LLC-PK1 cell models. Xenobiotica. 2008;38:1536-1550.

33. Li X, Choi JS. Effect of genistein on the pharmacokinetics of paclitaxel administered orally or intravenously in rats. Int J Pharm. 2007;337:188193.

34. Limtrakul $P$, Khantamat $O$, Pintha K. Inhibition of P-glycoprotein function and expression by kaempferol and quercetin. J Chemother. 2005;17:8695.

35. Wang G, Xiao CQ, Li Z, Guo D, Chen Y, Fan L, Qian RH, Peng XJ, Hu DL, Zhou $\mathrm{HH}$. Effect of soy extract administration on losartan pharmacokinetics in healthy female volunteers. Ann Pharmacother. 2009;43:1045-1049.

36. Wang $Q$, GE X, Tian X, Zhang Y, Zhang J, Zhang P. Soy isoflavone: The multipurpose phytochemical. Biomed Rep. 2013;1:697-701.

37. Setchell KDR, Brown NM, Zhao X, Lindley SL, Heubi JE, King EC, Messina MJ. Soy isoflavone phase II metabolism differs between rodents and humans: Implications for the effect on breast cancer risk. Am J Clin Nutr. 2011;94:1284-1294.

38. Lozovaya VV, Lygin AV, Ulanov AV, Nelson RL, Daydé J, Widholm JM. Effect of temperature and soil moisture status during seed development on soybean seed isoflavone concentration and composition. Crop Sci. 2005;45:1934-1940.

39. Ho HM, Chen RY, Leung LK, Chan FL, Huang Y, Chen ZY. Difference in flavonoid and isoflavone profile between soybean and soy leaf. Biomed Pharmacother. 2002;56:289-295.

40. Mebrahtu T, Mohamed A, Wang CY, Andebrhan T. Analysis of isoflavone contents in vegetable soybeans. Plant Foods Hum Nutr. 2004;59:55-61.

41. Andrade JE, Twaddle NC, Helferich WG, Doerge DR. Absolute bioavailability of isoflavones from soy protein isolate-containing food in female Balb/c mice. J Agric Food Chem. 2010;58:4529-4536.

42. Aresta A, Cotugno P, Massari F, Zambonin C. Determination of isoflavones in soybean flour by matrix solid-phase dispersion extraction and liquid chromatography with UV-diode array detection. J Food Qual. 2017;2017;1-5.

43. Orhan I, Ozcelik B, Kartal M, Aslan S, Sener B, Ozguven M. Quantification of daidzein, genistein and fatty acids in soybeans and soy sprouts, and some bioactivity studies. Acta Biol Cracoviensia Ser Bot. 2007;49:61-68.

44. Anupongsanugool E, Teekachunhatean S, Rojanasthien N, Pongsatha S, Sangdee C. Pharmacokinetics of isoflavones, daidzein and genistein, after ingestion of soy beverage compared with soy extract capsules in postmenopausal Thai women. BMC Clin Pharmacol. 2005;5:1-10.

45. Chen TR, Wei QK. Analysis of bioactive aglycone isoflavones in soybean and soybean products. Nutr Food Sci. 2008;38:540-547.

46. Chang Y, Choue R. Plasma pharmacokinetics and urinary excretion of isoflavones after ingestion of soy products with different aglycone/ glucoside ratios in South Korean women. Nutr Res Pract. 2013;7:393399.

47. Zhang J, Ge Y, Han F, Li B, Yan S, Sun J, Wang L. Isoflavone content of soybean cultivars from maturity group 0 to $\mathrm{VI}$ grown in northern and southern China. J Am Oil Chem Soc. 2014;91:1019-1028.

48. Cheng YQ, Zhu YP, Hu Q, Li LT, Saito M, Zhang SX, Yin LJ. Transformation of isoflavones during sufu (a traditional Chinese fermented soybean curd) production by fermentation with Mucor flavus at low temperature. Int J Food Prop. 2011;14:629-639.

49. Hong GE, Mandal PK, Lim K won, Lee CH. Fermentation increases isoflavone aglycone contents in black soybean pulp. Asian J Anim Vet Adv. 2012:502-511.

50. Kuligowski M, Pawłowska K, Jasińska-Kuligowska I, Nowak J. Composición de isoflavonas, contenido de polifenoles y actividad antioxidante de las semillas de soja durante fermentación de tempeh. CYTA J Food. 2016;15:27-33.

51. Riciputi Y, Serrazanetti DI, Verardo V, Vannini L, Caboni MF, Lanciotti R. Effect of fermentation on the content of bioactive compounds in tofutype products. J Funct Foods. 2016;27:131-139.

52. Da Silva LH, Celeghini RMS, Chang YK. Effect of the fermentation of whole soybean flour on the conversion of isoflavones from glycosides to aglycones. Food Chem. 2011;128:640-644.

53. Huang YH, Lai YJ, Chou CC. Fermentation temperature affects the antioxidant activity of the enzyme-ripened sufu, an oriental traditional fermented product of soybean. J Biosci Bioeng. 2011;112:49-53. 
54. Li S, Jin Z, Hu D, Yang W, Yan Y, Nie X, Jing L, Qingyu Z, Gai D, Ji Y, Chen $X$. Effect of solid-state fermentation with Lactobacillus casei on the nutritional value, isoflavones, phenolic acids and antioxidant activity of whole soybean flour. Lebensm Wiss Technol. 2020;125:109264.

55. Gardner CD, Chatterjee LM, Franke AA. Effects of isoflavone supplements vs. soy foods on blood concentrations of genistein and daidzein in adults. J Nutr Biochem. 2009;20:227-234.

56. Golkhoo S, Ahmadi AR, Hanachi P, Barantalab F, Vaziri M. Determination of daidzein and genistein in soy milk in Iran by using HPLC analysis method. Pakistan J Biol Sci. 2008;11:2254-2258.

57. Miura A, Sugiyama C, Sakakibara H, Simoi K, Goda T. Bioavailability of isoflavones from soy products in equol producers and non-producers in Japanese women. J Nutr Intermed Metab 2016;6:41-47.

58. Freddo N, Nardi J, Bertol CD, Dallegrave E, Leal MB, Barreto F. Isoflavone quantitation in soymilk: Genistein content and its biological effect. CYTA J Food. 2019;17:20-24.

59. Cassidy A, Brown JE, Hawdon A, Faughnan MS, King LJ, Millward J, Zimmer-Nechemias L, Wolfe B, Setchell KD. Factors affecting the bioavailability of soy isoflavones in humans after ingestion of physiologically relevant levels from different soy foods. J Nutr. 2006;136:45-51.

60. Haron H, Ismail A, Azlan A, Shahar S, Peng LS. Daidzein and genestein contents in tempeh and selected soy products. Food Chem. 2009;115:1350-1356.

61. Prabhakaran MP, Perera CO, Valiyaveettil S. Quantification of isoflavones in soymilk and tofu from South East Asia. Int J Food Prop. 2005;8:113123.

62. Lee MK, Kim JK, Lee SY. Effects of fermentation on SDS-PAGE patterns, total peptide, isoflavone contents and antioxidant activity of freezethawed tofu fermented with Bacillus subtilis. Food Chem. 2018;249:6065.

63. Faughnan MS, Hawdon A, Ah-Singh E, Brown J, Millward DJ, Cassidy A. Urinary isoflavone kinetics: the effect of age, gender, food matrix and chemical composition. Br J Nutr. 2004;91:567-574.

64. Laurenzana EM, Weis CC, Bryant CW, Newbold R, Delclos KB. Effect of dietary administration of genistein, nonylphenol or ethinyl estradiol on hepatic testosterone metabolism, cytochrome P-450 enzymes, and estrogen receptor alpha expression. Food Chem Toxicol. 2002;40:53-63.

65. Zheng X, Wen J, Liu TH, Ou-Yang QG, Cai JP, Zhou HY. Genistein exposure interferes with pharmacokinetics of celecoxib in SD male rats by UPLC-MS/MS. Biochem Res Int. 2017;2017;1-7.

66. Peng WX, Li H De, Zhou HH. Effect of daidzein on CYP1A2 activity and pharmacokinetics of theophylline in healthy volunteers. Eur J Clin Pharmacol. 2003;59:237-241.

67. Xiao CQ, Chen R, Lin J, Wang G, Chen Y, Tan ZR, Zhou HH. Effect of genistein on the activities of cytochrome P450 $3 \mathrm{~A}$ and P-glycoprotein in Chinese healthy participants. Xenobiotica. 2012;42:173-178.

68. Wang Z, Wang L, Xia MM, Sun W, Huang CK, Cui X, Hu GX, Lian QQ, Wang ZS. Pharmacokinetics interaction between imatinib and genistein in rats. Biomed Res Int. 2015;2015:368976.

69. Singh D, Asad M. Effect of soybean administration on the pharmacokinetics of carbamazepine and omeprazole in rats. Fundam Clin Pharmacol. 2010;24:351-355.

70. Jin H, Zhu Y, Wang C, Meng Q, Wu J, Sun P, Ma X, Sun H, Huo X, Liu $K$, Tan A. Molecular pharmacokinetic mechanism of the drug-drug interaction between genistein and repaglinide mediated by P-gp. Biomed Pharmacother. 2020;125:110032.

71. Perez M, Otero JA, Barrera B, Prieto JG, Merino G, Alvarez Al. Inhibition of $A B C G 2 / B C R P$ transporter by soy isoflavones genistein and daidzein: Effect on plasma and milk levels of danofloxacin in sheep. Vet J. 2013;196:203-208.

72. Marahatta A, Bhandary B, Jeong SK, Kim HR, Chae HJ. Soybean greatly reduces valproic acid plasma concentrations: $A$ food-drug interaction study. Sci Rep. 2014:4:1-7.

73. Mrozikiewicz PM, Bogacz A, Czerny B, Karasiewicz M, Kujawski R, Mikolajczak PL, Seremak-Mrozikiewicz A, Grzeskowiak E, BobkiewiczKozlowska T. The influence of a standardized soybean extract (Glycine max) on the expression level of cytochrome P450 genes in vivo. Ginekol Pol. 2010;81:516-520.

74. Bogacz A, Bartkowiak-Wieczorek J, Mikołajczak Pt, RakowskaMrozikiewicz B, Grześkowiak E, Wolski H, Czerny B, Mrozikiewicz PM. The influence of soybean extract on the expression level of selected drug transporters, transcription factors and cytochrome $P 450$ genes encoding phase I drug-metabolizing enzymes. Ginekol Pol. 2014;85:348-353.

75. Scott L, Durant P, Leone-Kabler S, Scott LM, Durant P, Leone-Kabler S, Wood CE, Register TC, Townsend A, Cline JM. Effects of prior oral contraceptive use and soy isoflavonoids on estrogen-metabolizing cytochrome P450 enzymes. J Steroid Biochem Mol Biol. 2008;112:179185.

76. Anderson GD, Rosito G, Mohustsy MA, Elmer GW. Drug interaction potential of soy extract and Panax ginseng. J Clin Pharmacol. 2003;43:643-648.

77. Kopecna-Zapletalova M, Krasulova K, Anzenbacher P, Hodek P, Anzenbacherova E. Interaction of isoflavonoids with human liver microsomal cytochromes P450: inhibition of CYP enzyme activities. Xenobiotica. 2016;47:324-331.

78. Isvoran A, Louet M, Vladoiu DL, Craciun D, Loriot MA, Villoutreix BO, Miteva MA. Pharmacogenomics of the cytochrome P450 2C family: impacts of amino acid variations on drug metabolism. Drug Discov Today. 2017;22:366-376.

79. Shimada T, Tanaka K, Takenaka S, Murayama N, Martin MV, Foroozesh MK, Yamazaki H, Guengerich FP, Komori M. Structure-function relationships of inhibition of human cytochromes P450 1A1, 1A2, 1B1, 2C9, and 3A4 by 33 flavonoid derivatives. Chem Res Toxicol. 2010;23;1921-1935.

80. Nebot N, Crettol S, Esposito F, Tattam B. Participation of CYP2C8 and CYP3A4 in the $\mathrm{N}$-demethylation of imatinib in human hepatic microsomes. Br J Pharmacol. 2010;161;1059-1069.

81. Coutre P, Kreuzer KA, Pursche S, Bonin M, Leopold T, Baskaynak G, Dörken B, Ehninger G, Ottmann O, Jenke A, Bornhäuser M, Schleyer E. Pharmacokinetics and cellular uptake of imatinib and its main metabolite CGP74588. Cancer Chemother Pharmacol. 2004:53;313-323.

82. Preissner S, Simmaco M, Gentile G, Preissner R. Personalized cancer therapy considering cytochrome P450 variability. Adv Pharmacol. 2015;74;113-130.

83. Moore LB, Goodwin B, Jones SA, Wisely GB, Serabjit-Singh CJ, Willson TM, Collins JL, Kliewer SA. St. John's wort induces hepatic drug metabolism through activation of the pregnane $X$ receptor. Proc Natl Acad Sci U S A. 2000;97:7500-7502.

84. Li Y, Ross-Viola JS, Shay NF, Moore DD, Ricketts M. Human CYP3A4 and murine CYP3A11 are regulated by equol and genistein via the pregnane $X$ receptor in a spesies-specific manner. J Nutr. 2009:139;898-904. 
85. Froyen EB, Reeves JLR, Mitchell AE, Steinberg FM. Regulation of phase II enzymes by genistein and daidzein in male and female Swiss Webster mice. J Med Food. 2009;12:1227-1237.

86. Pfeiffer E, Treiling CR, Hoehle SI, Metzler M. Isoflavones modulate the glucuronidation of estradiol in human liver microsomes. Carcinogenesis. 2005;26:2172-2178.

87. Galijatovic A, Walle UK, Walle T. Induction of UDP-glucuronosyltransferase by the flavonoids chrysin and quercetin in caco-2 cells. Pharm Res. 2000;17:21-26.

88. Mao Q, Lai Y, Wang J. Drug transporters in xenobiotic disposition and pharmacokinetic prediction. Drug Metab Dispos. 2018;46:561-566.

89. Lee SC, Arya V, Yang X, Volpe DA, Zhang L. Evaluation of transporters in drug development: Current status and contemporary issues. Adv Drug Deliv Rev. 2017;116:100-118.

90. Hagenbuch B, Meier PJ. The superfamily of organic anion transporting polypeptides. Biochim Biophys Acta Biomembr. 2003;1609:1-18.

91. Russel FGM, Masereeuw R. Molecular aspects of renal anionic drug transport. Annu Rev Physiol. 2002;64;563-594.

92. Jonker JW, Schinkel AH. Pharmacological and physiological functions of the polyspecific organic cation transporters: OCT1, 2, and 3.J Pharmacol Exp Ther. 2004;308:2-9.
93. Shugarts S, Benet LZ. The role of transporters in the pharmacokinetics of orally administered drugs. Pharm Res. 2009;26:2039-2054.

94. Robey RW, Pluchino KM, Hall MD, Fojo AT, Bates SE, Gottesman MM. Revisiting the role of $A B C$ transporters in multidrug-resistant cancer. Nat Rev Cancer. 2018;18;452-464.

95. Liu W, Meng Q, Sun Y, Changyuan W, Huo X, Liu Z, Sun P, Sun H, Ma $X$, and Liu K. Targeting P-glycoprotein : nelfinavir reverses adriamycin resistance in K562/ADR cells. Cell Physiol Biochem. 2018;51:1616-1631.

96. Ballent M, Lifschitz A, Virkel G, Sallovitz J, Maté L, Lanusse C. In vivo and ex vivo assessment of the interaction between ivermectin and danofloxacin in sheep. Vet J. 2012;192:422-427.

97. Mealey KL. ABCG2 transporter: therapeutic and physiologic implications in veterinary species. J Vet Pharmacol Ther. 2011;35;105-112.

98. Naya M, Imai M. Recent advances on soybean isoflavone extraction and enzymatic modification of soybean oil. London: IntechOpen; 2013:1-24.

99. Merino G, Perez M, Real R, Egido E, Prieto JG, Alvarez Al. In vivo inhibition of BCRP/ABCG2 mediated transport of nitrofurantoin by the isoflavones genistein and daidzein: A comparative study in Bcrp1-/- mice. Pharm Res. 2010;27:2098-2105. 